\title{
Apparent constant adult survival of a Sand Martin Riparia riparia population in relation to climatic variables
}

\author{
Giulia Masoero $^{1, *}$, Alberto Tamietti ${ }^{2}$, Giovanni Boano ${ }^{3}$ \& Enrico Caprio ${ }^{1,4}$
}

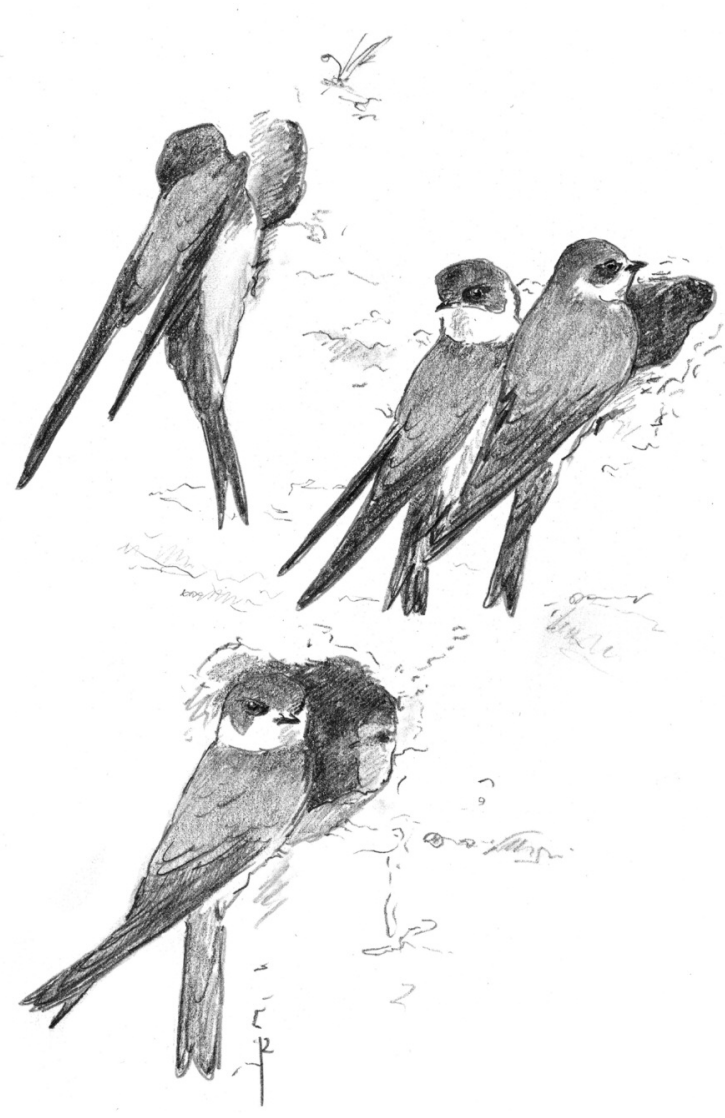

Masoero G., Tamietti A., Boano G. \& Caprio E. 2016. Apparent constant adult survival of a Sand Martin Riparia riparia population in relation to climatic variables. Ardea 104: 253-262. doi:10.5253/arde.v104i3.a1

The Sand Martin Riparia riparia is a trans-Saharan migrant species, whose populations are declining throughout Europe. We present the results of a multiple year study on a breeding population of Sand Martins along the River Po in Northern Italy through ringing breeding birds at nesting colonies (2002-2014). There was a trend for the abundance of the studied population to fluctuate. Recapture data were analysed to obtain apparent survival probabilities which differed between the sexes, but not between years. No apparent relationship was found between survival and three different meteo-climatic indices (North Atlantic Oscillation, Sahel rainfall and Lake Chad rainfall). During the 1980s and 1990s, winter survival was positively correlated with rainfall in the winter quarters. Although rainfall in the winter quarters has been more stable during the past 15 years, Sand Martin populations are still decreasing. Our findings suggest that the relationship with rainfall no longer holds, and that current population declines may be unrelated to climate in the winter quarters.

Key words: capture-mark-recapture, population dynamics, Riparia riparia, Sand Martin, climate

\begin{abstract}
${ }^{1}$ Università degli Studi di Torino, Dipartimento di Scienze della Vita e Biologia dei Sistemi, Via Accademia Albertina 13, 10123 Torino, Italy; ${ }^{2}$ Parco del Po e della Collina Torinese, Corso Trieste 98, Moncalieri (TO), Italy; ${ }^{3}$ Museo Civico di Storia Naturale di Carmagnola, Via San Francesco di Sales 188, Carmagnola (TO), Italy; ${ }^{4}$ Scuola di Biodiversità di Villa Paolina, c/o Consorzio Asti Studi Superiori - Piazzale F. De Andre', 14100 Asti, Italy;

*corresponding author (giulia.masoero@gmail.com)
\end{abstract}

Many bird populations are subject to wide fluctuations in abundance from one year to the next (Newton 1998, Sæther et al. 2002, 2016). These fluctuations are caused by losses and gains of individuals in the population. Survival, recruitment, emigration and immigration are the four key processes that cause demographic variation (Sibly \& Hone 2002). Variation in the survival probability of adults or juveniles and/or changes in reproductive success could strongly affect population size. Despite being an intensively investigated field, studying the main drivers of survival and reproduction has always proved to be a difficult task (Newton 1998). In more recent years though, a growing number of studies that investigate the relationship between demographic rates and fluctuations in population size have been published (e.g. Shaub \& Abadi 2011, Morrison et al. 2013, Robinson et al. 2014). Understanding how the environment affects populations is of fundamental interest both in ecological sciences and in conservation. In particular, it can allow the identification of the causes underlying population declines, and can help to target conservation efforts in ways that could halt or reverse a decline (Norris 2004, Shaub \& Abadi 2011).

Many species of long-distance migrants are decreasing across Europe (Sanderson et al. 2006, Both et al. 2010, Vickery et al. 2014) and the causes of the declines are often linked to climate change, which can act by altering phenology and breeding success (Both \& Visser 2001, Visser et al. 2004, Ambrosini et al. 2011). Here, we present the results of a study on Sand Martins Riparia riparia: a member of the Hirundinidae family that is threatened by changes in both climate and habitat (Garrison 1999, del Hoyo et al. 2004). The species is a trans-Saharan migrant (Mead 1979), which 
is common in Italy during the breeding season. In Europe, it is classified as Species of European Conservation Concern (SPEC) category 3 (Burfield \& van Bommel 2004) and as Least Concern according to the 2012 IUCN Red List Category, but the population trend has been assessed as decreasing worldwide, and it has experienced large-scale population declines since the early 1960s (Cowley 1979, Jones 1987, BirdLife International 2012). According to the most recent population assessment (BirdLife International 2015), Sand Martin populations are decreasing in many European countries and the Italian population is reported to be strongly decreasing (Brichetti \& Fracasso 2007, Campedelli et al. 2012).

Previous studies have established that climatic factors in the African wintering quarters are crucial in the annual life cycle of a wide range of Palearctic longdistance migrant birds (Peach et al. 1991, Szép 1995, Robinson et al. 2008, Norman \& Peach 2013). In particular, Sand Martin population surveys throughout Europe have shown the importance of climatic conditions in the wintering grounds: the sub-Saharan region of the Sahel (Kuhnen 1975, Cowley 1979, Svensson 1986, Persson 1987). Survival seems to be related to rainfall in the Sahel, which is usually characterized by a single wet season from June to October, and drought conditions appear to have a negative effect on survival. Severe dry conditions have characterized the years in which the studies of Kuhnen (1975), Cowley (1979), Svensson (1986) and Persson (1987) were carried out (i.e. 1970-1990; Nicholson 2000). During the past 15

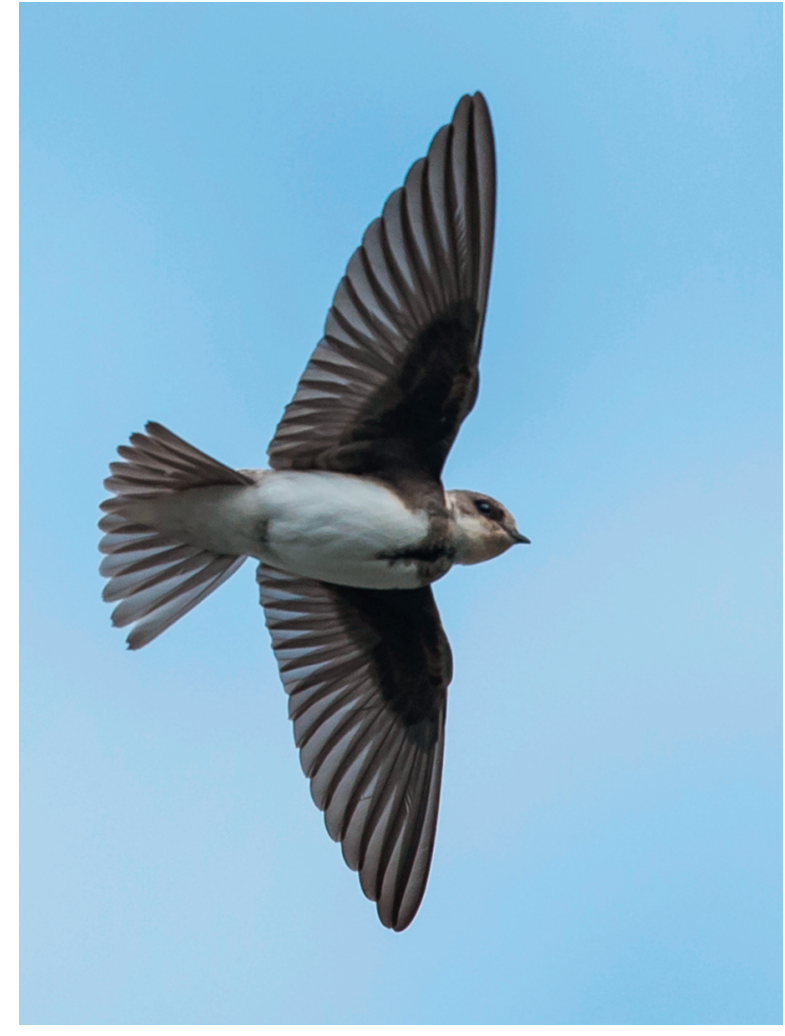

Sand Martin in flight (photo: B. Gai).

years, the Sahel has experienced less extreme conditions, with a more stable amount of summer rainfall (Evan et al. 2014, Sanogo et al. 2015).

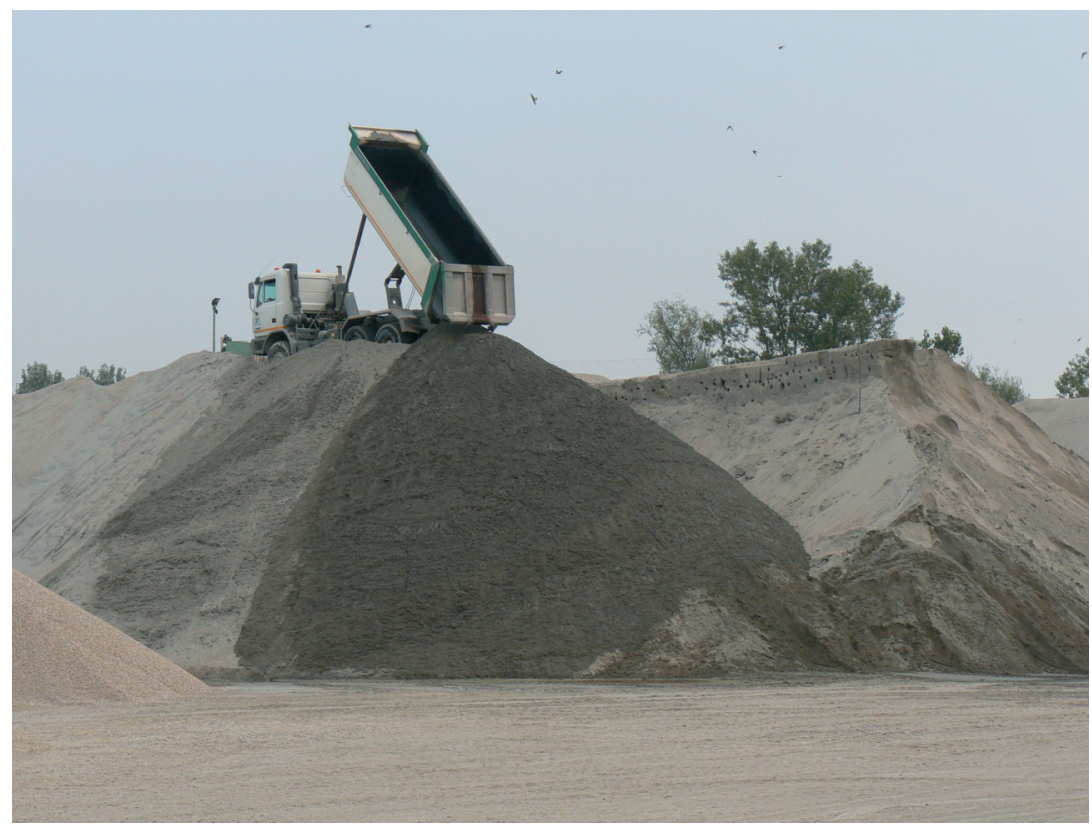

In June 2008, the Sand Martins built their nests in sand heaps very close to the working area of the quarry. 
We analysed ringing data from a Sand Martin population in north-western Italy collected over 12 years using capture-mark-recapture analysis. The aim of the study was to assess the trend in the studied population, to test relationships between survival and climate indices (Sahel rainfall and North Atlantic Oscillation (NAO)) in years in which drought conditions in the wintering grounds are not an issue, and therefore to better understand the population dynamics of this species.

\section{METHODS}

\section{Study area and breeding colonies}

The study area was located along a c. $25 \mathrm{~km}$ stretch of the river Po in the River Po and Collina Torinese Regional Park, to the south of Turin, Italy (between $44.971^{\circ} \mathrm{N}, 7.693^{\circ} \mathrm{E}$ and $44.832^{\circ} \mathrm{N}, 7.636^{\circ} \mathrm{E}$ ) and included all 15 commercially managed quarries that were present within the area. Nine quarries were active throughout the duration of this study. Building materials, such as sand and gravel, are excavated from the ground along the river course and, when the extraction is over, the quarry is usually restored to a more natural state. Sand Martins utilised active quarries because of the abundance of sand cliffs free of vegetation where they could build nests. The colonies were monitored from 2002 to 2016, and all active nesting holes were

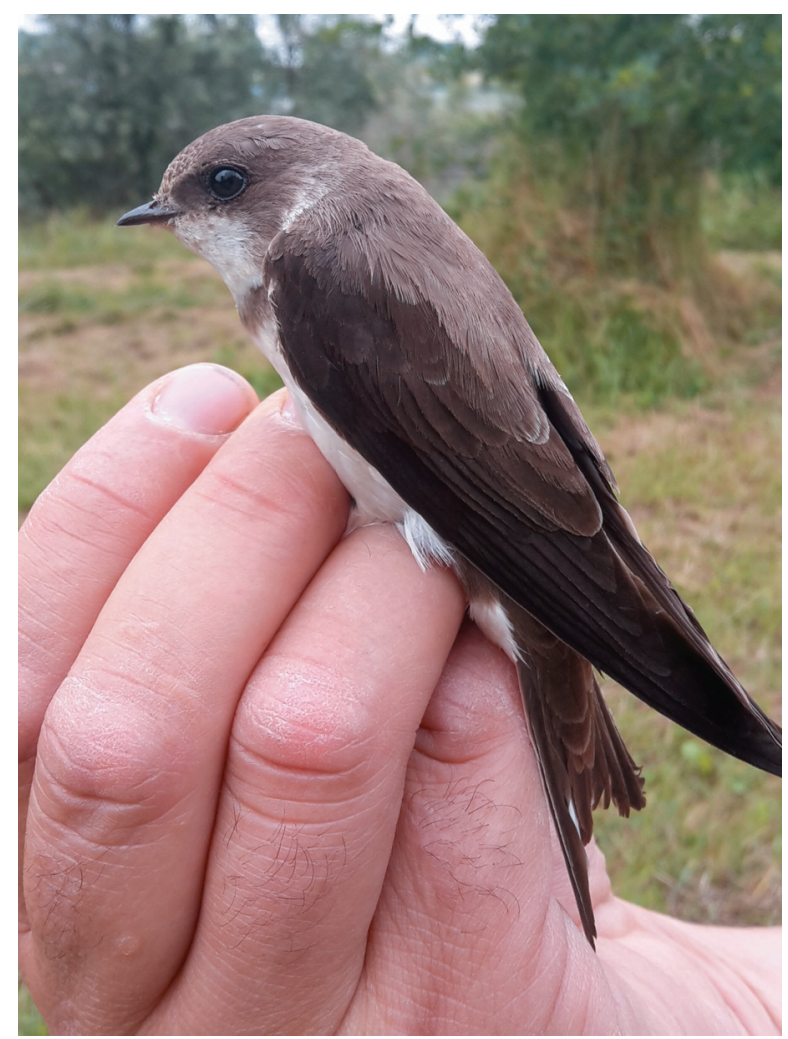

Adult Sand Martin photographed during a ringing session in June 2016.

Sand Martin colony near the quarry lake in June 2016.

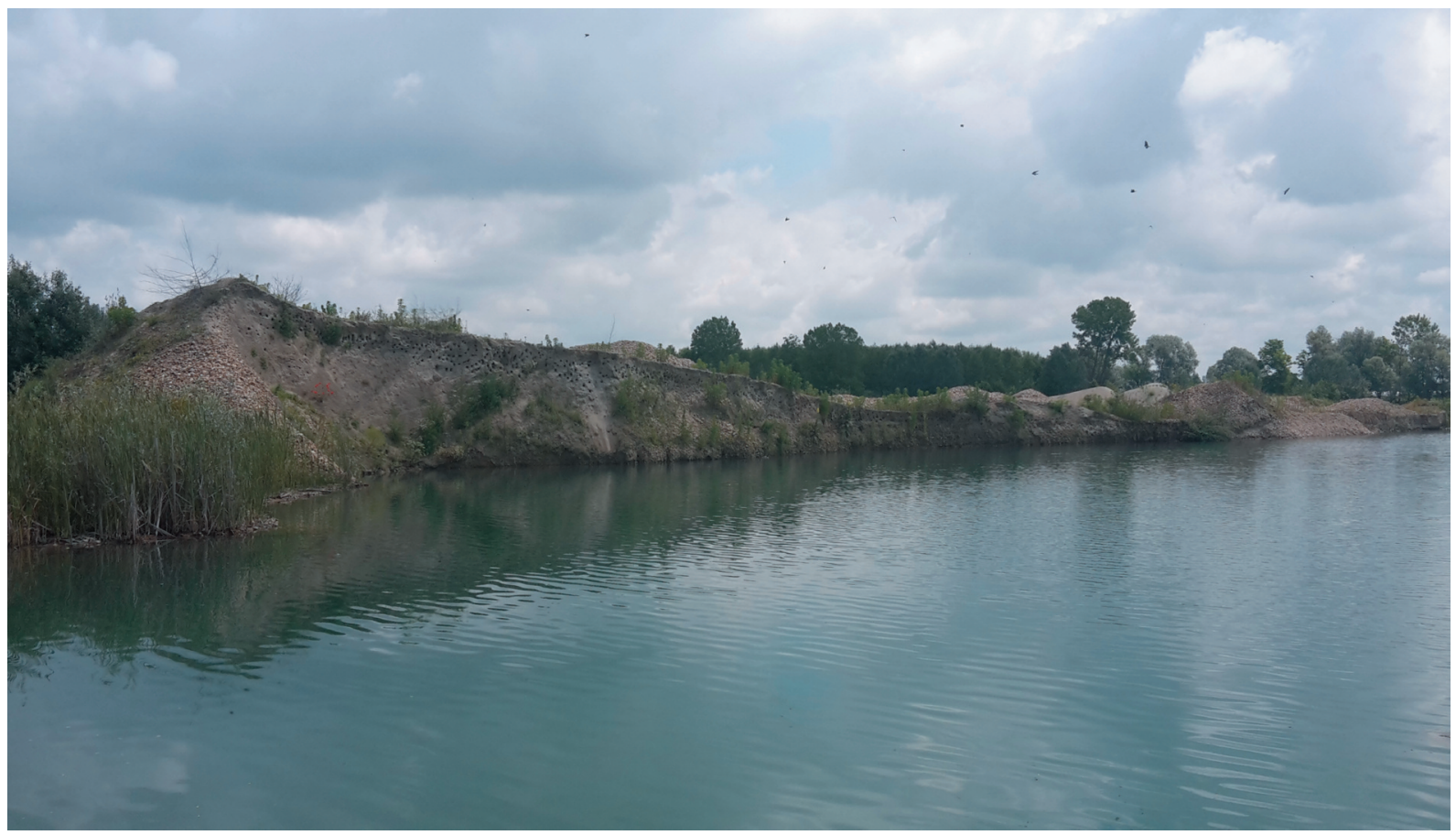


counted to provide an independent measure of changes in adult abundance. The population was divided into different colonies each year, occupying usually 2 or 3 different quarries.

Sand Martins were caught at breeding colonies using mist-nets, mostly in the morning. The number of capture sessions ranged from one to seven per year (at least one per colony) and took place between May and July from 2002 to 2014. Sand Martins were individually marked with numbered metal rings issued by the Italian Ringing Scheme (ISPRA - Istituto Superiore per la Protezione e la Ricerca Ambientale). Individuals were sexed according to the presence or absence of a brood patch and/or shape of the cloaca according to Cowley (1999) and aged as adults or juveniles (Svensson 1992).

\section{Mark-recapture analysis}

We estimated annual survival probabilities from capture-mark-recapture (CMR) data using multinomial probability models (Lebreton et al. 1992). These models allow for the incomplete registration of surviving and returning birds by describing the CMR data as the product of recapture and apparent survival probabilities. All survival and recruitment analyses were conducted using the software MARK v. 6.0 (White \& Burnham 1999). The database contained a total of 2856 adult Sand Martins (1364 males, 1179 females and 313 undetermined), of which 170 (84 males 80 females and 6 undetermined) were controlled one or more times during the subsequent years. For the analysis, we used only the data belonging to adult sexed Sand Martins (2543 individuals), because the number of recaptured juveniles was too small (8 out of 205 marked individuals). We started the analysis with a Cormack-Jolly-Seber (CJS) model for two groups (Lebreton et al. 1992), in which both survival and recapture could differ between years and between sexes. The model provided a reasonable description of the data according to the goodness-of-fit (GOF) tests computed with the program U-CARE (Choquet et al. 2005; overall GOF for both sexes combined: $\chi^{2}{ }_{44}=$ 18.9, $P>0.9$ ). We found no transient effect (test 3.SR: $\chi^{2}{ }_{10}=2.9, P>0.9$ for males and $\chi^{2}{ }_{11}=3.2, P>0.9$ for females), no trap-dependence effect (test 2.CT: $\chi^{2}{ }_{5}=$ 5.3, $P>0.3$ for males and $\chi^{2}{ }_{9}=3.2, P>0.9$ for females) nor any other structural problems (all $P$ 's for sex-specific tests 3.SM and 2.CL >0.3).

We attempted to simplify the CJS model to achieve a parsimonious description of the data by constraining model parameters to be constant across years and/or identical or additive across the sexes (Lebreton et al.
1992). We used Akaike's information criterion adjusted for small sample size ( $\mathrm{AIC}_{\mathrm{c}}$ ) to guide model selection (Burnham \& Anderson 2002, Lebreton et al. 1992). The model with the lowest $\mathrm{AIC}_{\mathrm{c}}$ value was chosen as the starting model for the subsequent analyses with climatic variables.

Due to the variation in the number of capture sessions, recapture probability was modelled to assess whether inter-annual variations were explained by the number of sessions or by the observed annual capture rate (i.e. the total number of adults captured divided by the total number of nest-holes).

\section{Survival and climate}

The relationship between adult survival and weather was then investigated in two important phases of the birds' life cycle: wintering and migration. The North Atlantic Oscillation index is a measure of the difference in the atmospheric pressure at sea-level between the Subtropical (Azores) High and the Subpolar (Iceland) Low and can provide an indication of weather along the migration route of the Sand Martins. We used the annual aggregated PC-based NAO index provided by the Climate Analysis section of NCAR, Boulder, USA (www.climatedataguide.ucar.edu/climate-data/hurrellnorth-atlantic-oscillation-nao-index-pc-based). In the wintering grounds, survival can be affected by droughts. Therefore, we decided to test Sahel and Chad rainfall as proxies of the rainfall in the West African winter quarters. This includes the area where Sand Martins winter (Robinson et al. 2008, Norman \& Peach 2013), and where the only African ringed bird recovered in Italy was from (Spina \& Volponi 2008).

The Sahel rainfall index was calculated as the mean (across weather stations) normalized anomaly covering the area between $10^{\circ}-20^{\circ} \mathrm{N}$ and $20^{\circ} \mathrm{W}-10^{\circ} \mathrm{E}$ for the main wet season between June and October, used in the aggregated form. Data were obtained from the Joint Institute for the Study of the Atmosphere and Ocean (JISAO), University of Washington, Seattle, USA (www.jisao.washington.edu/data_sets/sahel/). Previous studies have found a positive relationship between the Sahel rainfall index and bird survival (Kanyamibwa et al. 1990, Peach et al. 1991 Norman \& Peach 2013).

The second index is rainfall data relative to the area of the Lake Chad basin. The Chad basin is a portion of the Sahel Zone where the presence of large flocks of Sand Martins had been recorded (Fry et al. 1970, Gustafsson et al. 2003). Data were obtained from the USGS/EROS Data Center (EDC) (http://earlywarning. usgs.gov/fews/mapviewer/index.php?region =af, accessed on December 2014). 
The three weather variables were standardized to the mean. We tested for relationships between adult survival and the three potential weather variables by fitting models in which year-specific survival was constrained to be a linear logistic function of one of the

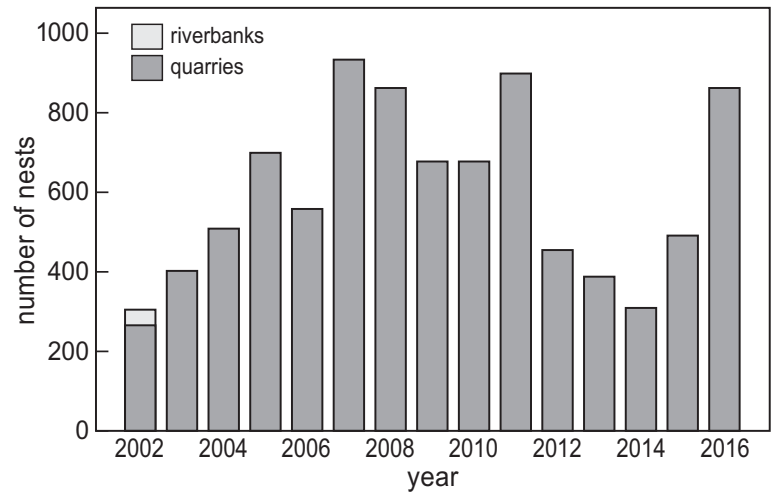

Figure 1. Number of nests per year from 2002 to 2016 counted during the censuses of the breeding colonies in riverbanks (light grey) and quarries (dark grey) respectively. potential covariates. We checked for non-linear covariate relationships by adding quadratic terms.

The AIC allows the most parsimonious model set, defined as those with $\Delta \mathrm{AIC}_{\mathrm{c}} \leq 2$, to be identified from various plausible candidates (Burnham \& Anderson 2002). We also applied analysis of deviance (ANODEV) to assess the statistical significance and relative strength of the covariates used in the model (Lebreton et al. 1992, Kéry et al. 2006). Model averaging was used to estimate annual survival probabilities.

\section{RESULTS}

\section{Nest count}

The number of active nest-holes ranged from a minimum of 305 in 2002 to a maximum of 934 in 2007 (Figure 1). A Generalized Additive Model of the number of nests in sand quarries against year revealed a significant non-linear positive relationship $\left(\chi_{8.996}^{2}=894.3\right.$, $P>0.001$, deviance explained $=90.5 \%)$. Only in the

Table 1. Modelling the survival $(\phi)$ and recapture $(p)$ probabilities of Sand Martins. Model subscripts represent dependence on year $(t)$ and gender $(g)$. Interactive effects are shown by $\times$ and additive effects by + . Covariates of recapture probability are capture rate $(\mathrm{CR})$ and number of sessions $(\mathrm{N})$. Covariates of survival are annual NAO index (NAO), JJASO Sahel rainfall index (Sahel, considering all the rainy season months) and annual Chad rainfall index (Chad). AIC $_{c}$ : Akaike's information criterion; n.p.: number of

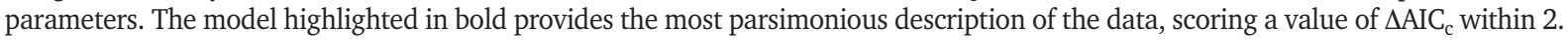

\begin{tabular}{|c|c|c|c|c|c|c|}
\hline Model & $\Delta \mathrm{AIC}_{\mathrm{c}}^{\mathrm{a}}$ & $\begin{array}{c}\mathrm{AIC}_{\mathrm{c}} \\
\text { Weight }\end{array}$ & $\begin{array}{c}\text { Model } \\
\text { Likelihood }\end{array}$ & n.p. & Deviance & $\begin{array}{l}\text { ANODEV ( } F, P ; \% \text { variation } \\
\text { explained) }\end{array}$ \\
\hline
\end{tabular}

Modelling recapture probability

\begin{tabular}{|c|c|c|c|c|}
\hline$\phi(g \times t) p(g \times t)$ & 6.23 & 0.01 & 0.04 & 39 \\
\hline$\phi(g \times t) p(g+t)$ & 7.38 & 0.01 & 0.02 & 33 \\
\hline$\phi(g \times t) p(t)$ & 14.39 & 0.00 & 0.00 & 33 \\
\hline$\phi(g \times t) p(\mathrm{CR})$ & 9.89 & 0.00 & 0.01 & 24 \\
\hline$\phi(g \times t) p(\mathrm{~N})$ & 27.06 & 0.00 & 0.00 & 24 \\
\hline$\phi(g \times t) p(g)$ & 27.57 & 0.00 & 0.00 & 24 \\
\hline$(g \times t) p()$. & 29.78 & 0.00 & 0.00 & 23 \\
\hline
\end{tabular}

Modelling survival rate

$\begin{array}{rlrllll}8) & \phi(g \times t) \mathrm{p}(g \times t) & 11.31 & 0.00 & 0.00 & 34 & 74.81 \\ 9) & \phi(t) p(g \times t) & 14.98 & 0.00 & 0.00 & 34 & 78.48 \\ 10) & \phi(g) p(g \times t) & \mathbf{0 . 0 0} & \mathbf{0 . 2 2} & \mathbf{1 . 0 0} & \mathbf{2 5} & \mathbf{8 1 . 9 3} \\ 11) & \phi(.) p(g \times t) & 2.33 & 0.07 & 0.31 & 24 & 86.31\end{array}$

Testing relationships with weather (all models with $p(g \times t)$ )

\begin{tabular}{llllllll}
$12)$ & $\phi\left(g \_N A O\right)$ & 0.19 & 0.20 & 0.91 & 26 & 80.08 & $F_{2,15}=1.960, P=0.180 ; 23.16$ \\
$13)$ & $\phi\left(g \_S a h e l\right)$ & 0.67 & 0.16 & 0.72 & 26 & 80.56 & $F_{2,15}=1.768, P=0.209 ; 21.39$ \\
$14)$ & $\phi\left(g \_C h a d\right)$ & 0.68 & $\mathbf{0 . 1 5}$ & $\mathbf{0 . 7 1}$ & 26 & $\mathbf{8 0 . 5 8}$ & $F_{2,15}=1.761, P=0.210 ; 21.32$ \\
$15)$ & $\phi\left(g \_N A O+\mathrm{NAO}^{2}\right)$ & 2.21 & 0.07 & 0.33 & 27 & 80.06 & $F_{3,15}=1.212, P=0.348 ; 23.25$ \\
$16)$ & $\phi\left(g \_S a h e l+\mathrm{Sahel}^{2}\right)$ & 2.67 & 0.06 & 0.26 & 27 & 80.51 & $F_{3,15}=1.099, P=0.387 ; 21.55$ \\
$17)$ & $\phi\left(g \_C h a d+\mathrm{Chad}^{2}\right)$ & 2.69 & 0.06 & 0.26 & 27 & 80.54 & $F_{3,15}=1.093, P=0.390 ; 21.45$ \\
\hline
\end{tabular}

${ }^{a}$ best model $\mathrm{AIC}_{\mathrm{c}}=1462.86$. 
first year of the study were we able to find nests in the riverbanks; during all other years the colonies were located in the adjacent quarries.

\section{Adult survival}

We investigated how adult recapture and survival probabilities $(\Phi)$ varied among years and between sexes (models 1-11, Table 1). We started from the most complex model for $\Phi$, with an interactive effect of time and sex, to model recapture probability. Adult recapture probability was dependent on an interactive effect of time and sex (model 1, Table 1). The pattern of interannual variation in recapture probabilities appeared to

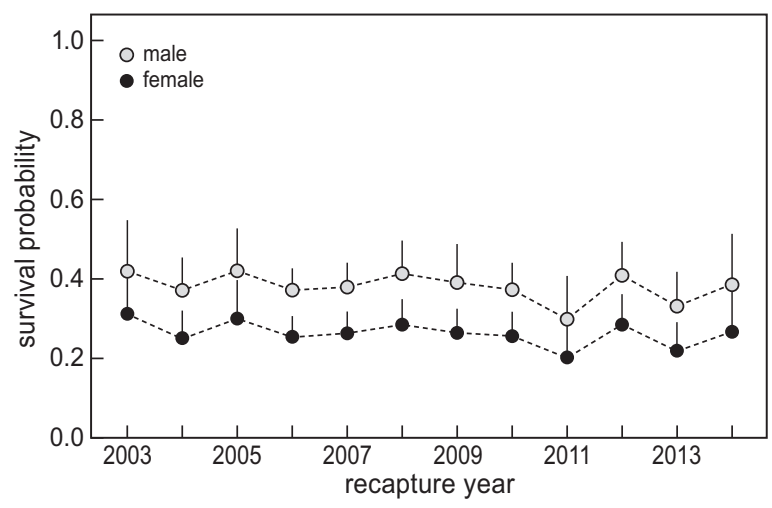

Figure 2. Variation in inter-annual apparent survival probabilities + standard error for male and female adult Sand Martins. Survival is plotted against its calendar year end points, called recapture year (e.g. survival during 2002-03 is plotted against 2003). be different between sexes, with an average value of $0.135 \pm 0.097$ for males and $0.247 \pm 0.177$ for females, over the course of the study. Capture rate was a significant positive predictor of inter-annual variation in recapture probability (model 4 , Table 1 ), but the $\mathrm{AIC}_{\mathrm{c}}$ was higher than that of model $1\left(\Delta \mathrm{AIC}_{\mathrm{c}}=3.66\right)$. Model 1 was therefore less parsimonious and the 95\%confidence interval of estimated capture rate overlapped zero. In modelling survival probability, the most parsimonious model showed a survival probability dependent on sex (model 10, Table 1). Apparent survival was on average $0.379 \pm 0.090$ for males and $0.262 \pm 0.081$ for females. It was therefore decided to retain the model 10 structure for survival and recapture probabilities in all subsequent modelling to avoid potential bias in survival estimates.

\section{Climate and survival}

Using the structure of model 10, we investigated the relationship between weather and winter survival (models 12-17, Table 1). The three linear models with meteo-climatic covariates (models 12, 13 and 14) had $\mathrm{AIC}_{\mathrm{c}}$ values higher than that of model 10, but too close to be considered different from it $\left(\triangle \mathrm{AIC}_{\mathrm{c}}<2\right)$. Models with the quadratic term (models 15, 16 and 17) had $\mathrm{AIC}_{\mathrm{c}}$ values higher than model 10 and with a $\Delta \mathrm{AIC}_{\mathrm{c}}<2$ compared to the best model. The 95\%-confidence interval of meteo-climatic variables also overlapped zero, meaning that the variables were not significantly different. ANODEV indicated that the variables did not add any significant explanation to the inter-annual variation in adult survival ( $P>0.05$ for all models).

Table 2. Estimate of inter-annual apparent survival $(\phi)$ and recapture ( $p$ ) probabilities and standard error (SE) for male and female adult Sand Martins. Year refers to the calendar year end points (e.g. survival during 2002-03 is referred to the year 2003).

\begin{tabular}{lcccccccc}
\hline Year & \multicolumn{2}{c}{$\phi$ (Males) } & \multicolumn{2}{c}{$\phi$ (Females) } & \multicolumn{2}{c}{$p$ (Males) } & \multicolumn{2}{c}{$p$ (Females) } \\
& Estimate & SE & Estimate & SE & Estimate & SE & Estimate & SE \\
\hline 2003 & 0.418 & 0.128 & 0.311 & 0.139 & 0.000 & 0.006 & 0.227 & 0.219 \\
2004 & 0.367 & 0.084 & 0.251 & 0.066 & 0.052 & 0.053 & 0.056 & 0.057 \\
2005 & 0.417 & 0.108 & 0.299 & 0.096 & 0.161 & 0.125 & 0.308 & 0.160 \\
2006 & 0.370 & 0.056 & 0.254 & 0.050 & 0.108 & 0.047 & 0.386 & 0.121 \\
2007 & 0.379 & 0.059 & 0.261 & 0.055 & 0.229 & 0.075 & 0.324 & 0.119 \\
2008 & 0.414 & 0.081 & 0.284 & 0.063 & 0.066 & 0.028 & 0.136 & 0.066 \\
2009 & 0.389 & 0.095 & 0.262 & 0.062 & 0.103 & 0.036 & 0.165 & 0.068 \\
2010 & 0.371 & 0.066 & 0.256 & 0.057 & 0.013 & 0.013 & 0.105 & 0.068 \\
2011 & 0.297 & 0.107 & 0.201 & 0.097 & 0.493 & 0.283 & 0.392 & 0.229 \\
2012 & 0.407 & 0.084 & 0.283 & 0.076 & 0.022 & 0.016 & 0.039 & 0.029 \\
2013 & 0.330 & 0.085 & 0.220 & 0.070 & 0.221 & 0.097 & 0.438 & 0.263 \\
2014 & 0.384 & 0.128 & 0.267 & 0.140 & 0.153 & 0.386 & 0.389 & 0.724
\end{tabular}


We calculated annual survival probabilities through model averaging of all $\Delta \mathrm{AIC}_{\mathrm{c}}<2$ models. Annual survival varied from 0.297 to 0.418 for males and from 0.201 to 0.311 for females (Table 2 and Figure 2). Apparent annual survival probabilities for males were significantly higher than for females ( $z$-test: $z=8.452$, $P>0.001)$.

\section{DISCUSSION}

Nest hole surveys showed that the number of adults and the number of nests changed over the course of the study period following a non-linear positive trend. Survival of adults in the studied population was not correlated with weather conditions in wintering areas, and the population was stable or even growing during the study period. Therefore, the obtained results seem to suggest that the amount of rainfall in the wintering grounds is currently not the main cause of the continued population decline observed at a European level (BirdLife International 2015).

\section{Adult survival}

The recapture probabilities varied between sexes and years. The latter was probably related to the capture rate, because, despite not being the most parsimonious model, capture rate was a significant positive predictor of inter-annual variations in recapture probability. The higher female recapture probabilities may be related to the variable and generally higher nest attentiveness of females as observed by Heneberg (2011).

The average survival probabilities were similar to those obtained in previous studies (Szép 1995, Cowley \& Siriwardena 2005, Norman \& Peach 2013), but showed a stronger and significant difference between males and females. Other studies, with the exception of Szép (1995), have reported lower apparent survival amongst female Sand Martins (males: $0.312 \pm 0.026$, females: $0.289 \pm 0.026$, in Cowley \& Siriwardena 2005; males: $0.380 \pm 0.012$, females: $0.318 \pm 0.012$, in Norman \& Peach 2013). As reported by Norman \& Peach (2013), this might partially be caused by a lower breeding site fidelity in females, but in our case there is a more marked difference, with values for males (0.379) similar to the second study, and very low values for females (0.262).

\section{Survival, climate and population trend}

We did not find relationships between Sand Martin survival and several meteo-climatic indices (Figure 3). The models with climatic variables had $\mathrm{AIC}_{\mathrm{c}}$-values

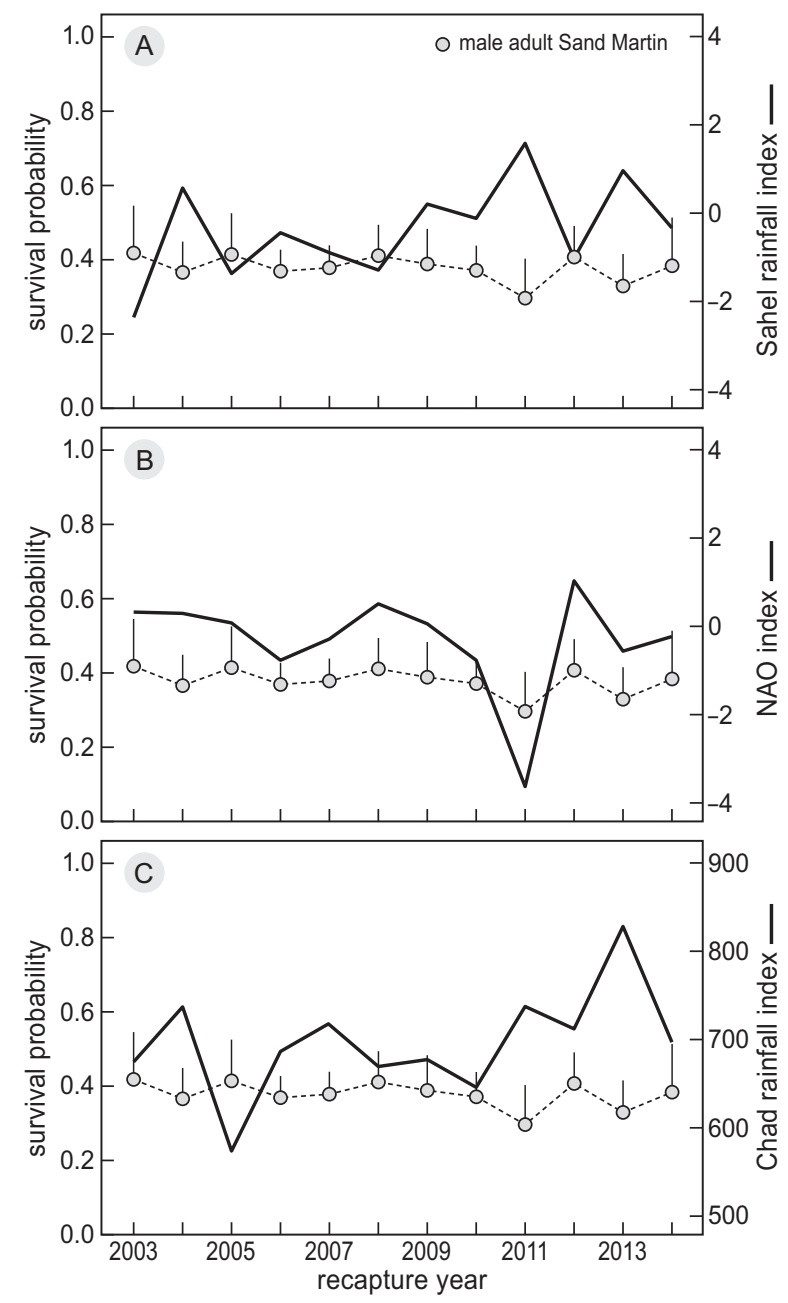

Figure 3. Variation in inter-annual apparent survival probabilities + standard error for male adult Sand Martins in relation to climatic variables: Sahel rainfall index (considering all the rainy season months; (A)), annual NAO index (B) and annual Chad rainfall index (C). All sets of variables are plotted against their calendar year end points, called recapture year (e.g. survival during 2002-03 is plotted against 2003).

very close to the best model without the meteo-climatic variables, and the confidence intervals included zero. However, the AIC scores suggest that there may be some weak influence of climate on survival. There could be several reasons for the lack of a clear relationship between survival probability and meteo-climatic variables. One might be the lack of accurate information on the location of the wintering grounds. We still do not have any recapture data in Africa for our Sand Martin population, while we know from recovery data that British birds are found in Mali, Mauritania and Senegal (Robinson et al. 2015). It is possible that the wintering grounds used by our population are different 


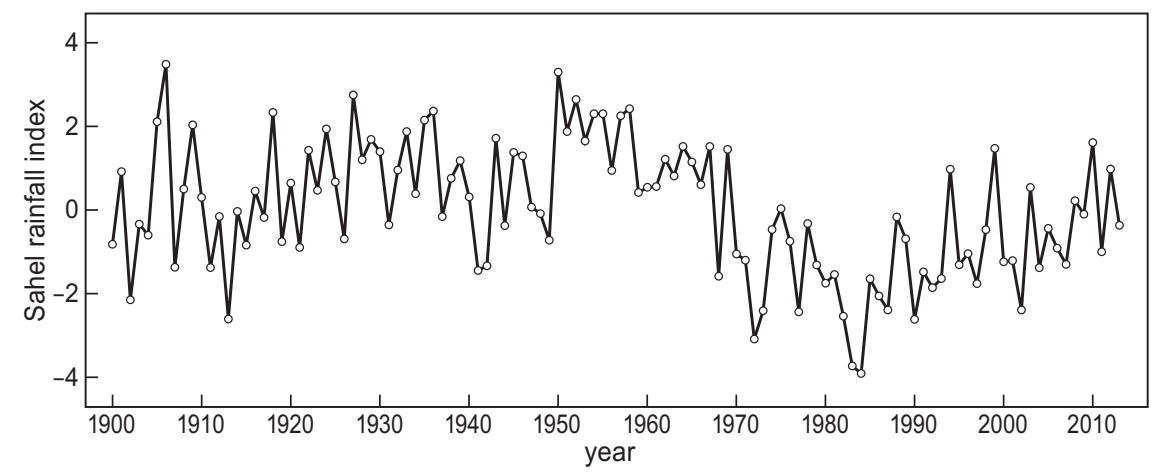

Figure 4. Variation in the Sahel rainfall index (mean normalized anomaly across weather stations) from 1990 to 2013.

from those used by the Sand Martins of the Hungarian populations studied by Szép (1995) and British populations studied by Cowley \& Siriwardena (2005) and Norman \& Peach (2013), where there was a strong relationship between mortality and low precipitation. These populations may therefore be subject to different conditions for which our data are not representative.

Another reason may be found by considering the annual survival values obtained in this study (Figure 2), their relationship with the climatic variables (Figure 3), and the Sahel rainfall index values of the last 114 years (Figure 4). First, the variation in survival probabilities among years (0.30-0.44 for males, $0.18-0.28$ for females) was not as pronounced as in other studies (for example: 0.11-0.66 for both males and females in Norman \& Peach 2013, and see Cowley \& Siriwardena 2005). Second, during the years considered in this study, the meteorological conditions were less extreme compared to those observed between 1970 and 2000. Several studies conducted in 1970-2000 found a relationship between survival and Sahel Rainfall index i.e. those of Szép (1995; monitoring years 1986-1994), Cowley \& Siriwardena (2005; 1967-1992) and Norman \& Peach $(2013 ;$ 1981-2003). These studies included a series of years with very strong drought due to reduced rainfall in the Sahel region (Nicholson 2000) which was correlated with a reduction in apparent survival probability. After this period, rainfall partially increased, and during the past 15 years this area has experienced a more stable amount of summer rainfall and no years with very dry conditions (Evan et al. 2015, Sanogo et al. 2015). This may have caused the lack of a relationship between weather and winter survival in our study.

Local causes of changes in population size could conceal the effects of variation in winter climate or habitat conditions. In contrast with national and European trends, the studied population has been char- acterized by fluctuating numbers with a positive trend (Figure 1). Although the relationship between Sahelian rainfall and survival seems to be the main cause underlying the population decline in the 1980s and 90s, other factors, such as habitat quality or loss may have recently become more severe. Sand Martins breeding along rivers require eroded vertical banks for nesting burrows, while riparian ecosystems are stressed by multiple human needs, and flood control infrastructures and channelization are affecting breeding Sand Martins worldwide (Moffatt et al. 2005). At the time of this study, our population was not nesting in riverbanks, but in the surrounding quarries, where it was guarded and monitored by the park staff, and hence it may have been relatively protected compared to other populations that may have suffered from the loss of nesting habitat.

\section{ACKNOWLEDGEMENTS}

We would like to thank all the people that helped us, and the River Po and Collina Torinese Regional Park. We are grateful to all the park staff (in particular E. Castello, F. Nobili and S. Zaghi), and to S. Blasutta, I. Ellena, S. Tozzi and G. Vaschetti for helping us in the Sand Martin capture procedures. D.E. Chamberlain's corrections and suggestions on the manuscript were very helpful and greatly appreciated. We also thank C. Okonkwo for helping us obtain the Chad Lake basin rainfall data. We acknowledge B. Gai for granting the use of his picture. Finally, we would like to thank C.A. Morrison and an anonymous referee for their comments on a previous version of the manuscript.

\section{REFERENCES}

Ambrosini R., Rubolini D., Møller A.P., Bani L., Clark J., Karcza Z., Vangeluwe D., Du Feu C., Spina F. \& Saino N. 2011. Climate change and the long-term northward shift in the African wintering range of the barn swallow Hirundo rustica. Clim. Res. 49: 131-141. 
Bellard C., Bertelsmeier C., Leadley P., Thuiller W. \& Courchamp F. 2012. Impacts of climate change on the future of biodiversity. Ecol. Lett. 15: 365-77.

BirdLife International. 2012. Riparia riparia. The IUCN Red List of threatened species 2012. www.iucnredlist.org/details/ 22712176/0. Accessed 2/2016.

BirdLife International. 2015. European Red List of Birds. Luxembourg: Office for Official Publications of the European Communities.

Both C., Bouwhuis S., Lessells C.M. \& Visser M.E. 2006. Climate change and population declines in a long-distance migratory bird. Nature 441: 81-83.

Both C. \& Visser M.E. 2001. Adjustment to climate change is constrained by arrival date in a long-distance migrant bird. Nature 411: 296-8.

Both C., van Turnhout C.A.M., Bijlsma R.G., Siepel H., van Strien A.J. \& Foppen R.P.B. 2010. Avian population consequences of climate change are most severe for long-distance migrants in seasonal habitats. Proc. Biol. Sci. 277: 1259-66.

Brichetti P. \& Fracasso G. 2007. Ornitologia italiana. Vol. 4. Apodidae - Prunellidae. Alberto Perdisa Editore, Bologna.

Burfield I. \& van Bommel F. 2004. Birds in Europe: population estimates, trends and conservation status. BirdLife International, Cambridge.

Burnham K.P. \& Anderson D.R. 2002. Model selection and multimodel inference: a practical information-theoretic approach. $2^{\text {nd }}$ ed. Springer, New York.

Campedelli T., Buvoli L., Bonazzi P., Calabrese L., Calvi G., Celada C., Cutini S., De Carli E., Fornasari L., Fulco E., La Gioia G., Londi G., Rossi P., Silva L. \& Tellini Florenzano G. 2012. Andamenti di popolazione delle specie comuni nidificanti in Italia: 2000-2011. Avocetta 36: 121-143.

Choquet R., Reboulet A.-M., Lebreton J.-D., Gimenez O. \& Pradel R. 2005. U-CARE 2.2 user's manual. CEFE, Montpellier, France.

Cowley E. 1979. Sand Martin population trends in Britain, 1965-1978. Bird Study 26: 113-116.

Cowley E. 1999. Sand Martin Riparia riparia - male or female? Ringing Migr. 19: 205-209.

Cowley E. \& Siriwardena G.M. 2005. Long-term variation in survival rates of Sand Martins Riparia riparia: dependence on breeding and wintering ground weather, age and sex, and their population consequences. Bird Study 52: 237-251.

Evan A.T., Flamant C., Lavaysse C., Kocha C. \& Saci A. 2014. Water vapor-forced greenhouse warming over the Sahara desert and the recent recovery from the Sahelian drought. J. Climate 28: 108-123.

Fry C.H., Ash J.S. \& Ferguson-Lees I.J. 1970. Spring weights of Palaearctic migrants at Lake Chad. Ibis 112: 58-82.

Garrison B.A. 1999. Bank Swallow (Riparia riparia). In: Rodewald P.G. (ed.) The birds of North America. Cornell Lab of Ornithology, Ithaca. https://birdsna.org/speciesaccount/bna/species/banswa. doi: 10.2173/bna.414

Gustafsson R., Hjort C., Ottosson U. \& Hall P. 2003. Birds at Lake Chad and the Sahel of NE Nigeria 1997-2000. The Lake Chad Bird Migration Project. Special report from Ottenby Bird Observatory. Degerhamn, Sweden.

del Hoyo J., Elliott A. \& Christie D. 2004. Handbook of the birds of the world. Vol. 9: Cotingas to pipits and wagtails. Lynx Edicions, Barcelona.

Heneberg P. 2011. Sex-specific differences in Sand Martin Riparia riparia nest attentiveness. Bird Study 58: 107-110.
Jones G. 1987. Selection against large size in the Sand Martin. Ibis 129: 274-280.

Kanyamibwa S., Schierer A., Pradel R. \& Lebreton J.-D. 1990. Changes in adult annual survival rates in a Western European population of the White Stork. Ibis 132: 27-35.

Kéry M., Madsen J. \& Lebreton J.-D. 2006. Survival of Svalbard pink-footed geese in relation to winter climate, density and land-use. J Anim. Ecol. 75: 1172-1181.

Kuhnen K. 1975. Bestandsentwicklung, Verbreitung, Biotop und Siedlungsdichte der Uferschwalbe (Riparia riparia) 19661973 am Niederrhein. Charadrius 11: 1-24.

Lebreton J.-D., Burnham K.P., Clobert J. \& Anderson D.R. 1992. Modeling survival and testing biological hypotheses using marked animals a unified approach with case studies. Ecol. Monogr. 62: 67-118.

Mead C.J. 1979. Colony fidelity and interchange in the Sand Martin. Bird Study 26: 99-106.

Moffatt K.C., Crone E.E., Holl K.D., Schlorff R.W. \& Garrison B.A. 2005. Importance of hydrologic and landscape heterogeneity for restoring bank swallow (Riparia riparia) colonies along the Sacramento River, California. Restoration Ecol. 13: 391-402.

Morrison C.A., Robinson R.A., Clark J.A., Risely K. \& Gill J.A. 2013. Recent population declines in Afro-Palaearctic migratory birds: the influence of breeding and non-breeding seasons. Divers. Distrib. 19: 1051-1058.

Newton I. 1998. Population limitation in birds. Academic Press, London.

Nicholson S.E. 2000. Land surface processes and Sahel climate. Rev. Geophys. 38; 117-139.

Norman D. \& Peach W.J. 2013. Density-dependent survival and recruitment in a long-distance Palaearctic migrant, the Sand Martin Riparia riparia. Ibis 155: 284-296.

Norris K. 2004. Managing threatened species: the ecological toolbox, evolutionary theory and declining-population paradigm. J. Appl. Ecol. 41: 413-426.

Peach W., Baillie S.R. \& Underhill L.G. 1991. Survival of British Sedge Warblers Acrocephalus schoenobaenus in relation to West African rainfall. Ibis 133: 300-305.

Persson C. 1987. Population processes in south-west Scanian Sand martins (Riparia riparia). J. Zool. 1: 671-691.

Robinson R.A., Balmer D.E. \& Marchant J.H. 2008. Survival rates of hirundines in relation to British and African rainfall. Ringing Migr. 24: 1-6.

Robinson R.A., Morrison C.A. \& Baillie S.R. 2014. Integrating demographic data: Towards a framework for monitoring wildlife populations at large spatial scales. Methods Ecol. Evol. 5: 1361-1372.

Robinson R.A., Leech D.I. \& Clark J.A. 2015. The Online Demography Report: bird ringing and nest recording in Britain \& Ireland in 2015. BTO, Thetford. www.bto.org/ ringing-report. Accessed 18/8/2016).

Sæther B.-E., Engen S. \& Matthysen E. 2002. Demographic characteristics and population dynamical patterns of solitary birds. Science 295: 2070-3.

Sæther B.-E., Grøtan V., Engen S., Coulson T., Grant P.R., Visser M.E., Brommer J.E., Grant B.R., Gustafsson L., Hatchwell B.J., Jerstad K. \& Karell P., Pietiäinen H., Roulin A., Røstad O.W. \& Weimerskirch H. 2016. Demographic routes to variability and regulation in bird populations Nat. Commun. 7: $1-8$. 
Sanderson F.J., Donald P.F., Pain D.J., Burfield I.J. \& Van Bommel F.P. 2006. Long-term population declines in AfroPalearctic migrant birds. Biol Conserv. 131: 93-105.

Sanogo S., Fink A.H., Omotosho J.A., Ba A., Redl R. \& Ermert V. 2015. Spatio-temporal characteristics of the recent rainfall recovery in West Africa. Int. J. Climatol. 35: 4589-4605.

Schaub M. \& Abadi F. 2010. Integrated population models: a novel analysis framework for deeper insights into population dynamics. J. Ornithol. 152: S227-S237.

Sibly R.M. \& Hone J. 2002. Population growth rate and its determinants: an overview. Philos. Trans. R. Soc. Lond. B. 357: 1153-1170.

Spina F. \& Volponi S. 2008. Atlante della Migrazione Atlante della Migrazione degli Uccelli in Italia volume II: Passeriformi. Ministero dell'Ambiente e della Tutela del Territorio e del Mare, Istituto Superiore per la Protezione e la Ricerca Ambientale (ISPRA). Tipografia SCR-Roma.

Stephens P.A., et al. 2016. Consistent response of bird populations to climate change on two continents. Science 352 : 84-87.

Svensson L. 1992. Identification guide to European passerines. Lars Svensson, Stockholm.

Svensson S. 1986. Number of pairs, timing of egg-laying and clutch size in a subalpine Sand Martin Riparia riparia colony, 1968-1985. Ornis Scand. 17: 221-229.

Szép T. 1995. Survival rates of Hungarian sand martins and their relationship with Sahel rainfall. J. Appl. Stat. 22: 891-904.

Vickery J.A., Ewing S.R., Smith K.W., Pain D J., Bairlein F., Škorpilová J. \& Gregory R.D. 2014. The decline of AfroPalaearctic migrants and an assessment of potential causes. Ibis 156: 1-22.

Visser M.E., Both C. \& Lambrechts M. 2004. Global climate change leads to mistimed avian reproduction. Adv. Ecol. Res. 35: 89-110.

White G.C. \& Burnham K.P. 1999. Program MARK: survival rate estimation from both live and dead encounters. Bird Study 46: S120-S139.

\section{SAMENVATTING}

Veel Europese langeafstandstrekkers nemen in aantal af. Die afname wordt vaak in verband gebracht met klimaatverandering. Dit is ook het geval bij de Oeverzwaluw Riparia riparia, waar voorheen langdurige droogtes in de Sahel waren gerelateerd aan een lagere overleving en populatieafname. Langdurige droogtes zijn echter in de laatste 15 jaar minder vaak voorgekomen. Toch neemt de Europese populatie nog steeds verder in aantal af. In dit artikel wordt van een geringde broedpopulatie van de Oeverzwaluw de relatie tussen overleving en klimatologische factoren in de Sahel in 2002-2014 onderzocht. De Oeverzwaluwen broedden in zandafgravingen lang de Po in het noorden van Italië. Alleen in het eerste onderzoeksjaar werden er nesten in de rivieroever gevonden. De broedvogelpopulatie fluctueerde sterk (tussen 300 en 900 broedparen). De jaarlijkse overleving van volwassen Oeverzwaluwen varieerde tussen de beide geslachten (mannetjes: 0,379; vrouwtjes: 0,262 ) en varieerde niet tussen de jaren. Er werd geen correlatie gevonden tussen de overleving en klimatologische factoren in het overwinteringsgebied, zoals de regenval in de Sahel. De onderzoekers concluderen dan ook dat de omstandigheden in het overwinteringsgebied tegenwoordig een kleinere rol in de populatieontwikkeling spelen dan voorheen en dat de oorzaak van de huidige afname van de broedvogelaantallen eerder in het broedgebied moet worden gezocht, zoals verslechtering en verdwijning van geschikt broedhabitat.

Corresponding editor: Roos Kentie

Received 27 April 2016; accepted 22 September 2016 